O.О. Гордєєв, канд. техн. наук Університет банківської справи Україна, 04070, Київ, вул. Андріївська, 1/1, тел. +38(044) 462 5305; e-mail: alex.gordeyev@ubs.edu.ua

\title{
Моделі якості та оцінки зручності використання інтерфейсу програмного забезпечення для людино-комп'ютерної взаємодії
}

\begin{abstract}
Побудовано моделі якості використання інтерфейсу програмного забезпечення (ПЗ) для людино-комп'ютерної взаємодії та моделі його оцінки. Такі моделі взаємопов'язані між собою через єдину номенклатуру підхарактеристик. Модель оцінювання якості зручності використання інтерфейсу ПЗ для людино-комп'ютерної взаємодії складається 3 двох частин та включає множину метрик, які відповідають визначеним підхарактеристикам. Особливістю моделі $\epsilon$ те, що усі примітиви для розрахунку метрик якості зручності використання інтерфейсу ПЗ для людино-комп'ютерної взаємодії отримано тільки за допомогою програмно-апаратного комплексу айтрекера.
\end{abstract}

Ключ о в $i$ сл о в а: інтерактивна якість, зручність використання ПЗ, людинокомп'ютерна взаємодія, метрики зручності використання.

Постановка задачі. Якість програмного забезпечення (ПЗ) нефункціональних вимог зазвичай описується характеристиками моделей якості ПЗ. Остання найбільш відома модель якості ISO/IEC 25010 включає вісім характеристик: функціональну придатність, продуктивність, сумісність, зручність використання, надійність, безпеку, супровідність і переносимість. Якість ПЗ як характеристика зручності використання повинна включати підхарактеристики, властиві якості інтерфейсу користувача як статичного об'єкта, а також підхарактеристики процесу взаємодії з користувачем, тобто це є людино-комп'ютерна взаємодія в реальному часі. В існуючих моделях якості та оцінки зручності використання не враховано особливості людино-комп'ютерної взаємодії в реальному часі. Користувач взаємодіє з ПЗ через інтерфейс. Якість інтерфейсу ПЗ визначається, з одного боку, характеристикою зручності використання як статичного об'єкта, а 3 іншого, - у взаємодії з користувачем.

(C) Гордєєв О.О., 2020 
Наведемо визначення зручності використання і людино-комп'ютерної взаємодії, а також визначимо взаємозв'язок між ними. Зручність використання - характеристика ПЗ, яке користувач може застосувати в певних умовах для досягнення встановлених цілей з необхідною ефективністю, результативністю та задоволеністю [1]. Людино-комп'ютерна взаємодія - це процес взаємодії між комп'ютером і користувачем через інтерфейс користувача, коли користувач, аналізуючи отриману інформацію (переважно зорову) від ПЗ, взаємодіє з ПЗ через інтерфейс, використовуючи для цього комп'ютерну клавіатуру, комп'ютерну мишку, вебкамеру тощо (рис. 1).

Експериментально встановлено, що якість використання людино-машинної взаємодії визначається не тільки якістю інтерфейсу користувача, дослідженням його досвіду, але і якістю людино-комп'ютерної взаємодії у реальному часі. Інтерактивність - це є безпосередня взаємодія користувача з ПЗ через клікання комп'ютерною мишкою. В той же час, користувач перебуває в процесі постійної «зорової» інтерактивності з інтерфейсом ПЗ.

В існуючих моделях якості та оцінки якості зручності використання П3 [1-12] інтерфейс користувача розглядається як статичний об'єкт і його інтерактивність взагалі не враховуєься, особливо в реальному часі. У роботах [13-15], присвячених дослідженню моделей якості ПЗ, не дано уточнення характеристики зручності використання і не включено в неї людино-машинну взаємодію, у тому числі в реальному часі. Тому розробка моделі якості зручності використання інтерфейсу ПЗ для людинокомп'ютерної взаємодії та відповідної моделі оцінки такої якості є надзвичайно актуальною.

Модель якості зручності використання людино-комп'ютерної взаємодії. Для розробки моделі будемо використовувати технологію айтрекінга, яка забезпечує оцінювання зорової інтерактивності і безпосередньої інтерактивності з інтерфейсом користувача.

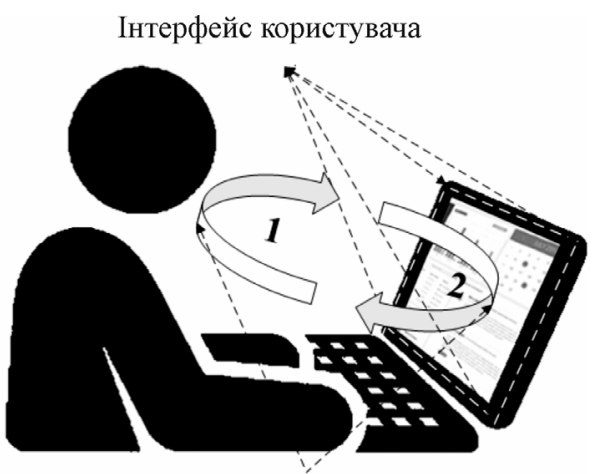

Людино-компютерна взаємодія

Puc. 1. Взаємозв'язок між зручністю використання та людино-комп'ютерною взаємодією: 1 - використання інтерфейсу користувача; 2 - отримання інформації від ПЗ 
Введемо деякі поняття і дамо їх визначення.

Дослідник - учасник процесу досліджень, який займається їх плануванням і проведенням.

Область інтересу AOI (Area of Interest) - обмежена область (периметр фігури прямокутника, кола, овалу тощо) досліджуваного об'єкта (наприклад, сторінки веб-сайту), для якої потрібно розраховувати метрики айтрекінга. Ця область може бути панеллю навігації, ПЗ, абзацем тексту, продуктом на полиці, рекламним щитом або знаком в аеропорту.

Саккади - швидкі, суворо узгоджені рухи очей, що відбуваються одночасно і в одному напрямку. Саккади займають не більше $10 \%$ загального часу рухів очей, а $90 \%$ часу очі утримуються на точках фіксації. Під час саккад мозок пригнічує сприйняття, тому людина не усвідомлює зсув очей від точки до точки.

Фіксація - нерухомий стан очей, під час якого відбувається розпізнавання об'єктів.

Айтрекінг (окулаграфія) - процес визначення координат погляду, тобто точки перетину оптичної осі очного яблука і площини об'єкта спостереження або екрана, на якому зображено деякий зоровий подразник.

Айтрекер (відслідковувач очей) - пристрій, який підтримує процес визначення орієнтації оптичної осі очного яблука в просторі, тобто пристрій, призначений для відстеження очей респондента.

Зоровий маршрут - вид візуалізації даних айтрекінга, який є картою, що показує розташування, порядок і час, витрачений респондентом, у відповідь на стимул, наприклад на веб-сторінку, роздруковане оголошення або відео. Послідовність точок погляду позначається цифрами. Час, витрачений на погляд, подається як тривалість фіксації і відповідає діаметру кола фіксації: чим довше дивишся, тим більший діаметр кола.

Сценарій дослідження - заздалегідь розроблений поетапний план проведення дослідження, який розробляється дослідником.

Розглянемо множину характеристик, які визначають якість зручності використання людино-комп'ютерної взаємодії та структуру іiі моделі (рис. 2). Характеристики якості зручності використання людино-машинної взаємодії поділяються на дві групи: 1) характеристики комплексного прийняття рішень; 2) характеристики інтерактивної уваги.

До першої групи входять такі характеристики:

видимість і пошук цілі - визначає успішність і швидкість знаходження необхідної мети;

розпізнавання цілі - визначає складність розпізнавання цілі;

характеристика прийняття рішення - характеризує складність (простоту) і швидкість прийняття рішення. 


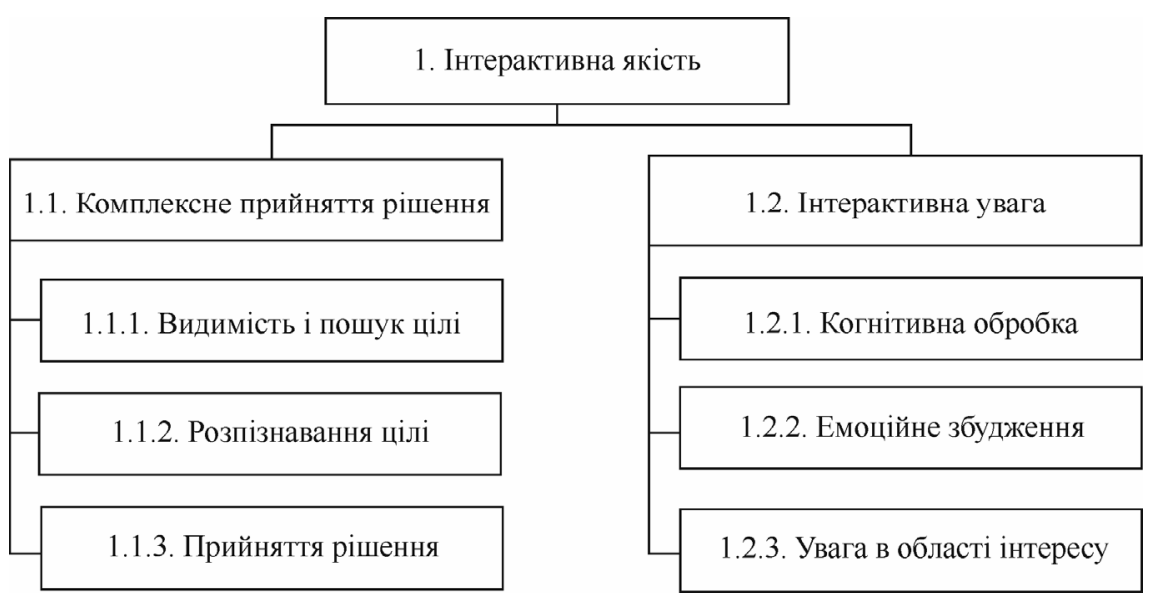

Puc. 2. Структурна схема моделі якості зручності використання інтерфейсу ПЗ для людино-комп'ютерної взаємодії

До другої групи входять такі характеристики:

когнітивна обробка - визначає швидкість обробки інформації респондентом;

емоційне збудження - характеризує рівень збудження в області інтересу і поза цією областю та динаміку збудження;

увага в області інтересу — визначає рівень і стійкість уваги в області інтересу.

Модель оцінювання якості зручності використання інтерфейсу ПЗ для людино-комп'ютерної взаємодії на основі айтрекінга. Процес айтрекінга передбачає наявність айтрекера та присутність респондента і дослідника. Респондент відповідно до заздалегідь розробленого сценарію виконує дії за комп'ютером, а айтрекер фіксує рух його очей під час цього процесу. Для цього айтрекер підсвічує інфрачервоним світлом очі респондента і записує відображення інфрачервоного світла від сітківки його очей. Така процедура дозволяє айтрекеру знайти центр зіниці респондента і дає можливість проаналізувати відображення інфрачервоного світла від рогівки.

Око респондента має сітківку, зіницю та рогівку (рис. 3):

сітківка - це світлочутлива тканина в задній частині ока, яку підсвічує айтрекер;

зіниця дозволяє інфрачервоному світлу проникнути на сітківку ока $\mathrm{i}$, відбившись від неї, через зіницю потрапити на світлочутливі камери айтрекера;

рогівка - прозора передня частина ока.

У кожному оці респондента є відображення світла від рогівки. Якщо респондент тримає голову нерухомо і дивиться ліворуч, праворуч, вгору 


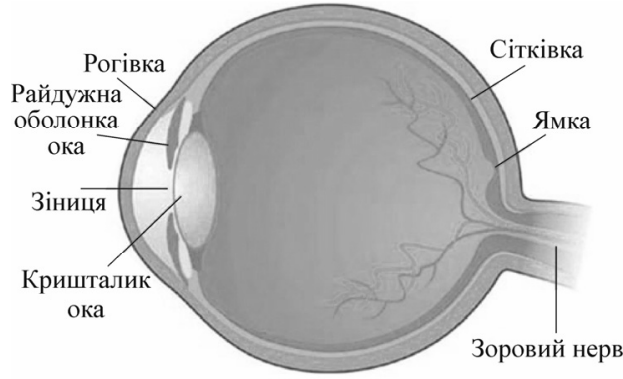

Рuc. 3. Будова людського ока

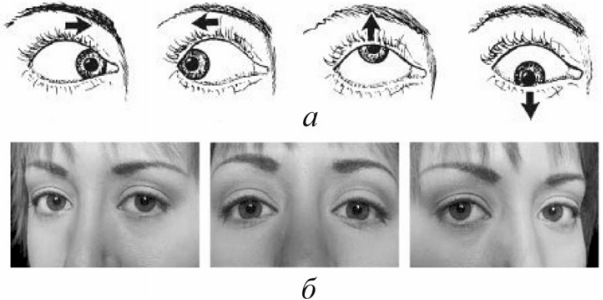

Рис. 4. Розташування зіниці (a) і відображення рогівки (б)

і вниз, відображення рухається разом з зіницею. Відстань між центром зіниці і відображенням світла при цьому змінюється (рис. 4, a). Отже, точку, на яку спрямовано погляд респондента, можна визначити через положення центру зіниці щодо відображення рогівки. Якщо він рухає головою, дивлячись на те саме місце, відстань між центром зіниці і відображенням рогівки залишається незмінною (рис. 4, б). Навіть якщо він рухається, айтрекер визначить, що людина дивиться на ту саму точку.

Сучасні комерційні айтрекери складаються з двох компонентів: джерела світла, наближеного до інфрачервоного, яке створює відображення в оці людини, і відеокамери, чутливої до інфрачервоного світла (рис. 5). Камера фокусується на очах респондента і записує відображення. 3 використанням ПЗ, яке підтримує роботу айтрекера, розраховується розташування погляду і накладається на об'єкт, наприклад веб-сторінку. Айтрекер використовує довжину хвилі, невидимої для людини, а відтак, не відволікає її увагу, але відбивається оком.

Очі респондента покривають поле зору близько $180^{\circ}$ по горизонталі (діапазон зорової інформації - $90^{\circ}$ ліворуч та $90^{\circ}$ праворуч) і $90^{\circ}$ по вертикалі (див. рис. 5). Коли очі респондента відкриті, образ того, що він бачить, проектується на сітківку. Клітини сітківки перетворюють цей образ в сигнали, які передаються в мозок. Клітини, відповідальні за гостроту зору, зосереджені в центрі сітківки, який називається ямкою (див. рис. 3). При погляді на об'єкт його зображення потрапляє на очні ямки респондента, і об'єкт виглядає значно чіткіше і яскравіше, ніж образи і предмети, які перебувають за межами ямки.

Площа ямки охоплює тільки два градуси від всього діапазону зорової інформації. Такі пропорції часто порівнюють з розміром мініатюри на відстані витягнутої руки. Навіть якщо респондент зазвичай не усвідомлює цього, зображення стає розмитим зовні ямки в області, що нази- 
вається фокусом уваги $\left(2^{\circ}\right)$, і ще більш розмитим на периферії (рис. $6, a$ ). Тому рухи очей необхідні, щоб тримати зображення в фокусі. Це важливий інформаційно-фільтраційний замісний механізм людини, який допомагає розвантажувати мозок. Якби фокус уваги займав усі $180^{\circ}$, мозок людини був би перевантажений інформацією.

На рис. 6, $a$, показано реальний фокус уваги оператора на людиномашинному інтерфейсі системи управління АЕС. Зображення в фокусі уваги завжди чітке і чим далі від місця фокусування, тим менша чіткість предметів. На рис. 6,6 , зображено уявний фокус уваги внаслідок руху очей і роботи мозку оператора, коли створюється враження чіткості всього діапазону зорової інформації.

Очі респондента переміщуються в середньому три-чотири рази в секунду. Такі швидкі рухи очей називаються саккадами і вони є найшвидкійшими рухами, які виконуються зовнішніми частинами людського тіла. Для запобігання помутніння зір людини практично повністю пригнічується під час саккад. Візуальна інформація сприймається тільки тоді, коли очі відносно нерухомі і зосереджені на якомусь об'єкті, тобто відбувається фіксація. Вона триває від 0,1 до 0,5 с, після чого очі знову рухаються (через саккади) до наступної частини поля зору. Отже, людський зір перебуває в постійному русі, від поточної фіксації через саккаду до нової фіксації.

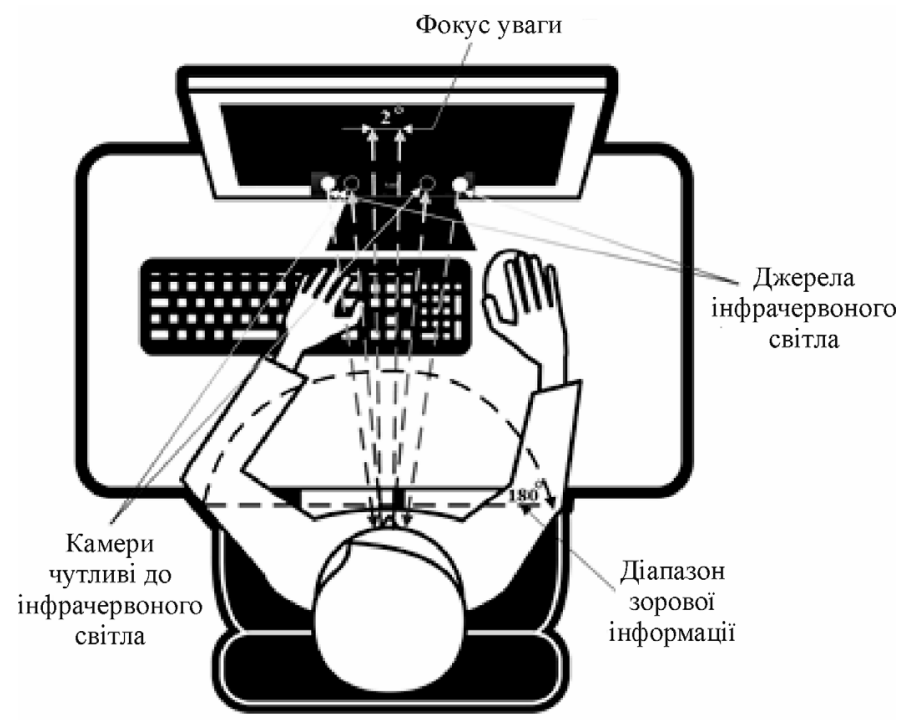

Puc. 5. Схематичне зображення айтрекера: діапазон зорової інформації $180^{\circ}$, фокус уваги $2^{\circ}$ 


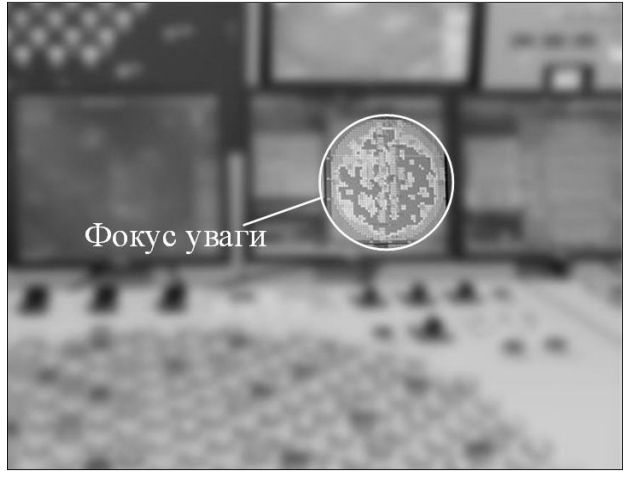

$a$

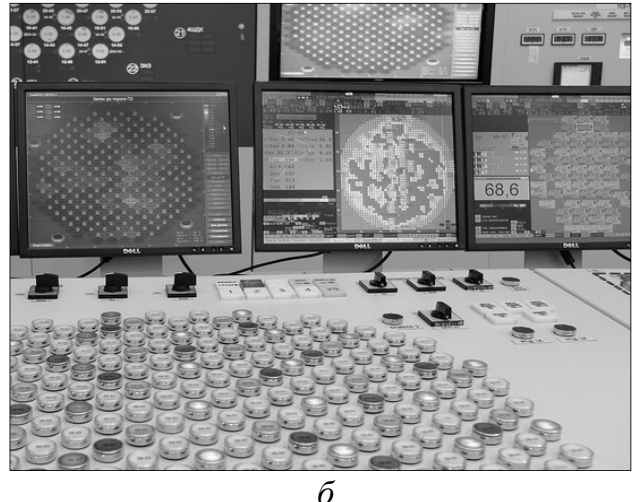

б

Puc. 6. Реальний (a) та уявний (б) фокус уваги оператора на людино-машинному інтерфейсі системи управління АЕС

На рис. 7 наведено зоровий маршрут респондента, який дивиться на реєстраційну форму конференції. Фіксації подано у вигляді точок, а саккади - у вигляді ліній, що з'єднують точки фіксації. Розмір точки пропорційний тривалості фіксації. Айтрекінг передбачає інтерактивне оцінювання не усього інтерфейсу користувача, а обмеженої його області, наприклад текстового поля, елемента управління тощо. Така область називається областю інтересу АОI. На одному об'єкті таких областей може бути декілька.

Інтерактивна якість зручності використання людино-комп'ютерної взаємодії доповнює основну якість зручності використання людинокомп'ютерної взаємодії. При описі моделі оцінювання інтерактивної взаємодії слід врахувати, що відповідно до сценарію дослідження користувач, задіяний у двох паралельних процесах:

1) візуальної взаємодії, коли відстежується рух його очей, який описується послідовністю саккад і фіксацій, що чергуються; оскільки саккада - це логічний перехід між фіксаціями, будемо враховувати тільки фіксації, і назвемо такий процес візуальною інтерактивністю;

2) безпосередньої взаємодії з інтерфейсом користувача 3 використанням комп'ютерної миші та натисканні ії лівої кнопки при управлінні інтерфейсом; такий процес назвемо реальною інтерактивністю.

У рамках означених процесів необхідні вимірювання будуть відбуватися в певні дискретні інтервали часу. Для візуальної інтерактивності повинні фіксуватися: лічильник дискретних вимірів, час фіксації виміру, координати фокусу уваги. Реальна інтерактивність включає всі вимірювані величини візуальної фіксації і додається параметр (подія) - натискання лівої кнопки комп'ютерної мишки. 


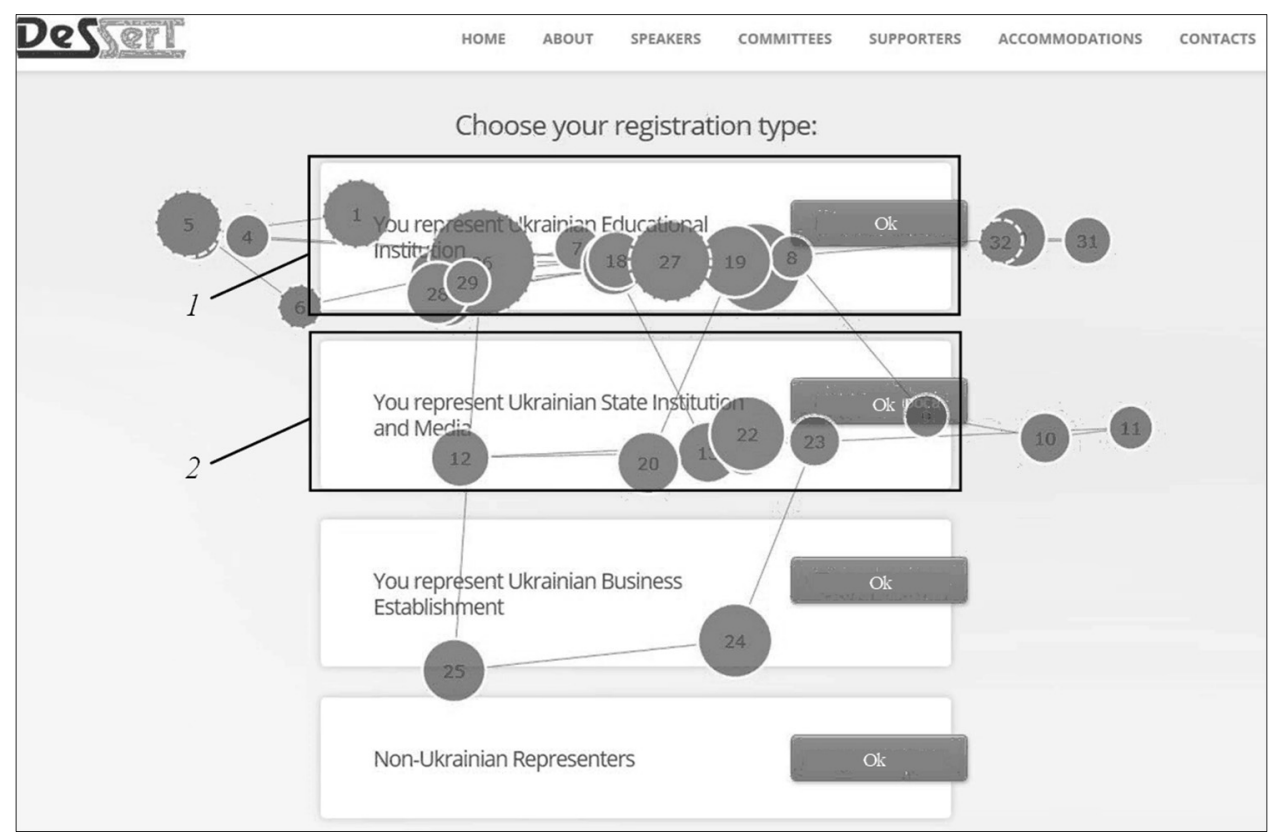

Рuc. 7. Області інтересу $(1,2)$ і зоровий маршрут респондента

Таким чином, для опису зазначеної моделі відповідно до візуальної і реальної інтерактивності введемо три наступних множини елементів моделі:

VI - множина даних візуальної взаємодії користувача з інтерфейсом користувача,

$$
V I=\left\{N,\left\{t_{i}, x_{i}, y_{i}\right\}_{i=1}^{N}\right\},
$$

де $N$ - кількість дискретних вимірювань (може збігатися з кількістю фіксацій); $t_{i}$ - час вимірювання; $x_{i}, y_{i}$ - координати фіксації;

$R I$ - множина даних взаємодії користувача 3 інтерфейсом користувача з використанням комп'ютерної миші,

$$
R I=\left\{N,\left\{t_{j}, x_{j}, y_{j}, c_{j}\right\}_{j=1}^{N}\right\},
$$

де $x_{j}, y_{j}$ - координати перебування курсору мишки; $c_{j}$ - подія натискання лівою кнопкою комп'ютерної миші (кнопка миші може бути натиснута (1), або не натиснута (0));

$A O I$ - множина областей інтересу,

$$
A O I=\{a o i\}_{j=1}^{n}
$$




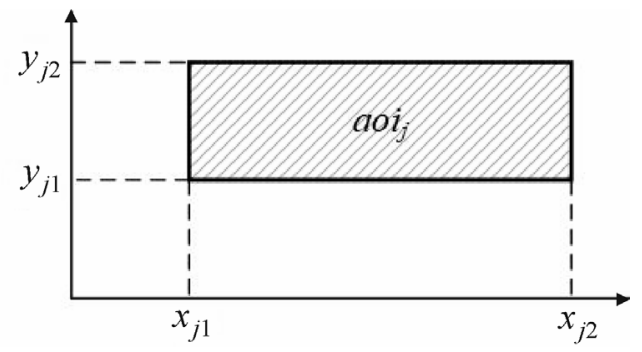

Puc. 8. Область інтересу $a о i_{j}$ в площині координат

де $a о i_{j}$ - область интересу. Зауважимо, що слід відокремлювати дані, зафіксовані в зоні інтересу i за іiі межами. У площині координатних осей введемо значення для опису області інтересу: на осі абсцис $-x_{j 1}, x_{j 2}$, на осі ординат $-y_{j 1}, y_{j 2}$ (рис. 8).

Для опису попадання значень координат $x$ i $y$ в область інтересу використаємо наступні характеристичні функції:

$$
\begin{gathered}
W_{j x}(x)=\left(\begin{array}{l}
1,\left(x \geq x_{j 1}\right) \wedge\left(x \leq x_{j 2}\right), \\
0,\left(x<x_{j 1}\right) \vee\left(x>x_{j 2}\right),
\end{array}\right. \\
W_{j y}(y)=\left\{\begin{array}{l}
1,\left(y \geq y_{j 1}\right) \wedge\left(y \leq y_{j 2}\right), \\
0,\left(y<y_{j 1}\right) \vee\left(y>y_{j 2}\right) .
\end{array}\right.
\end{gathered}
$$

Зазвичай область інтересу приблизно дорівнює елементу інтерфейсу користувача. На практиці чіткої рівності не існує, оскільки експерт визначає розташування зони інтересу не за координатами, а візуально. Отже, координати елемента інтерфейсу користувача та області інтересу приблизно рівні:

$$
\begin{aligned}
& x_{j 1} \approx \text { spsuie }_{1} \in \text { SPSUIE }, \quad x_{j 2} \approx \text { fpsuie }_{1} \in \text { FPSUIE }, \\
& y_{j 1} \approx \text { spsuie }_{2} \in \text { SPSUIE }, \quad y_{j 2} \approx \text { fpsuie }_{2} \in \text { FPSUIE },
\end{aligned}
$$

де SPSUIE (Start Position of Software User Inter face Element) - початкова позиція елемента інтерфейсу користувача П3; spsuie - координати $x$ та $y$ лівого верхнього кута елемента інтерфейсу користувача; FPSUIE (Final Position of Software User Interface Element) - кінцева позиція елемента інтерфейсу користувача; fpsuie - координати $x$ та $y$ правого нижнього кута елемента інтерфейсу користувача.

Розглянемо реальний приклад дослідження якості інтерфейсу користувача веб-сайту конференції (рис. 9). Задамо початкові значення: область інтересу - елемент інтерфейсу користувача «Пояснювальна інформація». Клікі комп'ютерною мишкою позначено номерами на точках фіксації. 


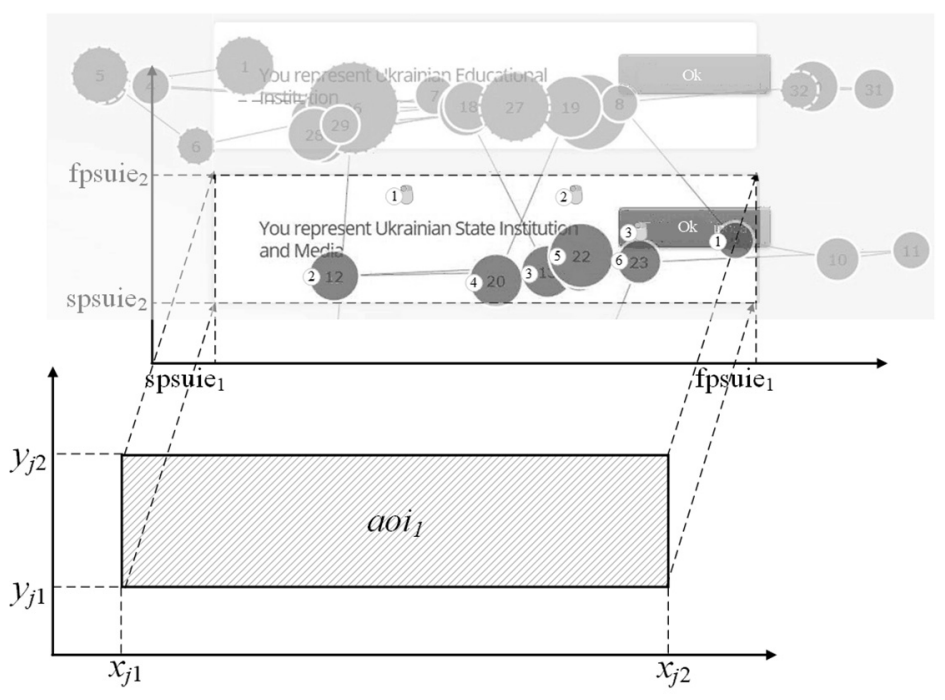

Рuc. 9. Відповідність області $a о i_{1}$ елементу інтерфейсу користувача

Вважаючи, що вимірювання здійснюються один раз в секунду, отримаємо наступні значення множин $V I$ та $R I$ :

$$
\begin{aligned}
& V I=\left\{\begin{array}{l}
\{1,38,4\}_{1}^{17},\{2,38,4\}_{2}^{17},\{3,8,3\}_{3}^{17}, \\
\{4,8,3\}_{4}^{17},\{5,8,3\}_{5}^{17},\{6,24,3\}_{6}^{17}, \\
\{7,24,3\}_{7}^{17},\{8,24,3\}_{8}^{17},\{9,20,2\}_{9}^{17}, \\
\{10,20,2\}_{10}^{17},\{11,20,2\}_{11}^{17},\{12,26,4\}_{12}^{17}, \\
\{13,26,4\}_{13}^{17},\{14,26,4\}_{14}^{17},\{15,26,4\}_{15}^{17}, \\
\{16,30,3\}_{16}^{17},\{17,30,3\}_{17}^{17} ;
\end{array}\right. \\
& R I=\left\{\begin{array}{l}
\{1,14,8,0\}_{1}^{17},\{2,14,8,0\}_{2}^{17},\{3,14,8,0\}_{3}^{17}, \\
\{4,14,8,0\}_{4}^{17},\{5,14,8,0\}_{5}^{17},\{6,14,8,1\}_{6}^{17}, \\
\{7,14,8,0\}_{7}^{17},\{8,26,8,0\}_{8}^{17},\{9,26,8,0\}_{9}^{17}, \\
\{10,26,8,0\}_{10}^{17},\{11,26,8,0\}_{11}^{17},\{12,26,8,0\}_{12}^{17},
\end{array}\right. \\
& \{13,26,8,1\}_{13}^{17},\{14,26,8,0\}_{14}^{17},\{15,30,5,0\}_{15}^{17}, \\
& \{16,30,5,1\}_{16}^{17},\{17,30,5,0\}_{17}^{17} .
\end{aligned}
$$


Опис метрики оцінювання інтерактивної якості

\begin{tabular}{|c|c|c|c|c|}
\hline Ідентифікатор & $V I / R I$ & Назва метрики & Опис & Формула (примітиви) \\
\hline IM1 & $V I$ & $\begin{array}{l}\text { SSGU - успіш- } \\
\text { ність пошуку ці- } \\
\text { лі користувачем }\end{array}$ & $\begin{array}{l}\text { Розраховується на } \\
\text { основі співвідношен- } \\
\text { ня кількості ко- } \\
\text { ристувачів, які знай- } \\
\text { шли ціль, до зага- } \\
\text { льної кількості ко- } \\
\text { ристувачів }\end{array}$ & $\begin{array}{l}\mathrm{SSGU}=U I / A U, \\
\text { де } U I-\text { кількість ко- } \\
\text { ристувачів, які зве- } \\
\text { ртають увагу на об- } \\
\text { ласть інтересу, } A U- \\
\text { загальна кількість } \\
\text { користувачів }\end{array}$ \\
\hline
\end{tabular}

Проаналізувавши отримані значення множин VI і $R I$, можна стверджувати наступне: кількість дискретних вимірів для опису візуальної інтерактивності множини VI дорівнює 17. Зазвичай декілька дискретних вимірювань відповідають одній фіксації: фіксація № 1 відповідає вимірюванням 1 і 2; фіксація № 2 - вимірюванням $3-5$; № $3-6-8$; № $4-$ $9-11$; № $5-12-15$; № $6-16,17$. Для множини $R I-$ було три натискання на ліву кнопку мишки під час 6, 13 і 16 дискретних вимірювань.

Розроблено номенклатуру метрик оцінювання якості зручності використання ПЗ для людино-комп'ютерного взаємодії. Попередньо було встановлено, що всі метрики за логікою можна розділити на дві великі групи: метрики віртуальної інтерактивності і метрики реальної інтерактивності. Детальний аналіз метрик засвідчив, що вони можуть бути класифіковані більш детально і точно на рівні груп послідовних етапів.

Отже, всі метрики класифіковано наступним чином: група метрик «Комплексне прийняття рішення» розділена за послідовністю етапів «видимість і пошук мети», «розпізнавання цілі» і «ухвалення рішення», а група метрик «Інтерактивна увага» - за послідовністю етапів «когнітивна обробка», «емоційне збудження» і «увага в області інтересу». Для того щоб зберегти взаємозв'язок між метриками і процесами віртуальної і реальної інтерактивності, для кожної метрики передбачено співвідношення з відповідним процесом - VI або $R I$. Приклад опису метрики наведено в таблиці.

\section{Висновки}

Запропоновані моделі описують інтерактивну якість зручності використання інтерфейсу ПЗ для людино-комп'ютерної взаємодії, а також забезпечують ії кількісну оцінку за допомогою певних груп метрик та показників. Це дає змогу збільшити точність, повноту та достовірність оцінки. Особливість моделі полягає в тому, що всі примітиви для розрахунку метрик отримуються тільки за допомогою програмно-апаратного комплексу айтрекеру. Планується розробити інструментальний засіб, який бу- 
де підтримувати процес оцінки інтерактивної якості зручності використання інтерфейсу ПЗ для людино-комп’ютерної взаємодії. Доцільно впроваджувати отримані результати у новий перспективний напрямок розвитку кіберінтерфейсів.

\section{СПИСОК ВИКОРИСТАНОЇ ЛІТЕРАТУРИ}

1. International standard ISO/IEC 25010:2011. Systems and software engineering - Systems and software Quality Requirements and Evaluation (SQuaRE) - System and software quality models. International Organization for Standardization, International Electrotechnical Commission, Institute of Electrical and Electronics Engineers, 2011, 34 p.

2. International standard ISO/IEC 9126-1:2001. Software engineering - Product quality. Part 1: Quality model. International Organization for Standardization, International Electrotechnical Commission. Institute of Electrical and Electronics Engineers, 2001, 25 p.

3. International standard ISO 9241-11:2018. Ergonomics of human-system interaction - Part 11: Usability: Definitions and concepts. International Organization for Standardization, International Electrotechnical Commission, Institute of Electrical and Electronics Engineers, $2018,29 \mathrm{p}$.

4. International standard ISO/IEC 14764:2006. Software Engineering - Software Life Cycle Processes - Maintenance. International Organization for Standardization, International Electrotechnical Commission, Institute of Electrical and Electronics Engineers, 2006, 44 p.

5. Seffah A., Donyaee M., Kline R., Padda H. Usability measurement and metrics: A consolidated model // Software Quality Journal, 2006, Vol. 14(2), pp. 159-178. http://DOI.org/ 10.1007/s11219-006-7600-8.

6. Rawashdeh A., Bassem M. New Software Quality Model for Evaluating COTS Components // Journal of Computer Science,2006, Vol 2 (4), pp.373-381.

7. Upadhyay N., Despande B., Agrawal V. Towards a Software Component Quality Model// Computer Science and Information TechnologyProc. of the $1^{\text {st }}$ Int. Conf., Penang, Malaysia, February 22-24, 2011, Springer, 2011, pp. 398-412. http://DOI.org/10.1007/978-3642-17857-3_40.

8. Shneiderman B., Plaisant C. Designing the User Interface: Strategies for Effective Human-Computer Interaction //Pearson; 4th Edition, 2004, 672 p.

9. Montero F., Lopez-Jaquero V., Lozano M., Gonzalez Montero P. Usability and web site evaluation. Quality models and user testing evaluations// Enterprise Information Systems: Proc. of the 5th Int. Conf., Angers, France, April 23-26, 2003, Springer, 2003, pp. 525-528.

10. Georgiadoui E. GEQUAMO-A Generic, Multilayered, Customizable Software Quality model// Software Quality Control Journal, 2003, Vol. 11 (4), pp. 313-323.

11. International standard ISO/IEC 25022:2016 Systems and software engineering - Systems and software Quality requirements and evaluation (SQuaRE) - Measurement of quality in use. International Organization for Standardization, International Electrotechnical Commission, Institute of Electrical and Electronics Engineers, 2016, 41 p.

12. International standard ISO/IEC 25023:2016 Systems and software engineering - Systems and software Quality Requirements and Evaluation (SQuaRE) - Measurement of system and software product quality. International Organization for Standardization, International Electrotechnical Commission, Institute of Electrical and Electronics Engineers, 2016, 45 p.

13. Gordieiev $O$., Kharchenko V., Leontiiev K. Usability, security and safety interaction: profile and metrics based analysis // Dependability and Complex Systems: Proc. of the 13 Int. Conf. (DepCoS-RELCOMEX). Brunow, Poland, July 2-6, 2018, Springer, 2018, pp. 238247. DOI: 10.1007/978-3-319-91446-6_23. 
14. Gordieiev O., Kharchenko V., Vereshchak K. Usable Security Versus Secure Usability: an Assessment of Attributes Interaction // ICT in Education, Research and Industrial Applications. Integration, Harmonization and Knowledge Transfer: Proc. of the 13th Int. Conf. (ICTERI), Kyiv, Ukraine, May 15-18, 2017, pp. 727-740.

15. Gordieiev O., Kharchenko V., Fusani M. Evolution of software quality models: usability, security and greenness issues // Computers: Proc. of the 19-th Int. Conf. (part of CSCC 15), Zakynthos Island, Greece, July 16-20, 2015. Zakynthos Island., 2015, pp. 519-523.

Отримано 22.09.2020

\section{REFERENCES}

1. International standard ISO/IEC 25010:2011. (2011), "Systems and software engineering Systems and software Quality Requirements and Evaluation (SQuaRE) - System and software quality models", International Organization for Standardization, International Electrotechnical Commission, Institute of Electrical and Electronics Engineers.

2. International standard ISO/IEC 9126-1:2001. (2001), "Software engineering - Product quality. Part 1: Quality model”, International Organization for Standardization, International Electrotechnical Commission. Institute of Electrical and Electronics Engineers.

3. International standard ISO 9241-11:2018. (2018), "Ergonomics of human-system interaction - Part 11: Usability: Definitions and concepts", International Organization for Standardization, International Electrotechnical Commission, Institute of Electrical and Electronics Engineers.

4. International standard ISO/IEC 14764:2006. (2006), "Software Engineering - Software Life Cycle Processes - Maintenance", International Organization for Standardization, International Electrotechnical Commission, Institute of Electrical and Electronics Engineers.

5. Seffah, A., Donyaee, M., Kline, R. B. and Padda, H. K. (2006), "Usability measurement and metrics: A consolidated model", Software Quality Journal, Vol. 14, no. 2, pp. 159. 178. DOI: http://doi.org/10.1007/s11219-006-7600-8

6. Rawashdeh, A. and Bassem, M. A. (2006), "New Software Quality Model for Evaluating COTS Components", Journal of Computer Science, Vol. 2, no. 4, pp. 373-381.

7. Upadhyay, N., Despande, B. and Agrawal, V. (2011), "Towards a Software Component Quality Model", Proceedings of the $1^{\text {st }}$ International Conference on Computer Science and Information Technology, Penang, Malaysia, February 22-24, 2011, pp. 398-412. DOI: http://doi.org/10.1007/978-3-642-17857-3 40

8. Shneiderman, B. and Plaisant, C. (2004), Designing the User Interface: Strategies for Effective Human-Computer Interaction, Pearson, 4th Edition.

9. Montero, F., Lopez-Jaquero, V., Lozano, M. and Gonzalez, P. (2003), "Usability and web site evaluation. Quality models and user testing evaluations", Proceedings of the 5th International Conference on Enterprise Information Systems, Angers, France, April 23-26, pp. 525-528.

10. Georgiadoui, E. (2003), "GEQUAMO-A Generic, Multilayered, Customizable Software Quality model”, Software Quality Control Journal, Vol.11, no. 4, pp. 313-323.

11. International standard ISO/IEC 25022:2016. (2016), "Systems and software engineering Systems and software Quality requirements and evaluation (SQuaRE) - Measurement of quality in use", International Organization for Standardization, International Electrotechnical Commission, Institute of Electrical and Electronics Engineers.

12. International standard ISO/IEC 25023:2016. (2016), "Systems and software engineering Systems and software Quality Requirements and Evaluation (SQuaRE) - Measurement of system and software product quality", International Organization for Standardization, International Electrotechnical Commission, Institute of Electrical and Electronics Engineers. 
13. Gordieiev, O., Kharchenko, V. and Leontiiev, K. (2018), "Usability, security and safety interaction: profile and metrics based analysis", Proceedings of the 13 International Conference on Dependability and Complex Systems (DepCoS-RELCOMEX), Brunow, Poland, July 2-6, pp. 238-247. DOI: http://doi.org/10.1007/978-3-319-91446-6_23

14. Godieiev, O., Kharchenko, V. and Vereshchak, K. (2017), "Usable Security Versus Secure Usability: an Assessment of Attributes Interaction", Proceedings of the 13th International Conference on ICT in Education, Research and Industrial Applications. Integration, Harmonization and Knowledge Transfer (ICTERI), Kyiv, Ukraine, May 15-18, pp. 727-740.

15. Gordieiev, O., Kharchenko, V. and Fusani, M. (2015), "Evolution of software quality models: usability, security and greenness issues", Proceedings of the 19-th International Conference on Computers (part of CSCC 15), Zakynthos Island, Greece, July 16-20, pp. 519-523.

Received 22.09.2020

\section{O. Gordieiev}

\section{QUALITY MODELS AND ASSESSMENT OF SOFTWARE INTERFACE USABILITY FOR HUMAN-COMPUTER INTERACTION}

The article proposes models of interactive quality and evaluating the interactive quality of the usability of the software interface for human-computer interaction. Such models are interconnected due to a single nomenclature of subcharacteristics. The model for assessing the interactive quality of the usability of the software interface for human-computer interaction consists of two parts and includes many metrics that correspond to the specified sub-characteristics. A feature of this model is that all the primitives for calculating the indicated metrics of the interactive quality of the usability of the software interface for human-computer interaction can be obtained only with the help of the software and hardware complex for the eye-tracker.

K e y w o r d s: interactive quality, software usability, human-computer interaction, interactive usability metrics.

ГОРДССВ Олександр Олександрович, канд. техн. наук, доцент, завідувач кафедри кібербезпеки Університету банківської справи. У 2003 році закінчив Наџіональний аерокосмічний університет ім. М.С. Жуковського «ХАI». Область наукових інтересів оцінка та забезпечення якості програмного забезпечення, дослідження людино-комп'ютерної взаємодії. 